\title{
Leasing: An Alternative Financing Mechanism for SMEs
}

\section{Md. Mosharref Hossain}

Lecturer, Bangladesh Institute of Bank Management (BIBM), BANGLADESH

\begin{abstract}
In almost every developing country Small and Medium enterprises (SMEs) are treated as the engine for economic growth and the availability of external finance for them is a topic of significant research interest to academics and policy makers around the globe. SMEs need improved access to finance especially for acquiring capital equipment and applications of new technology for operations. However, their access to finance is restricted because they do not have reliable credit histories, adequate capitalization or additional assets for collateral. Most of the financial institutions are reluctant to provide term loans or cash flow based lending to the SME sector. Thus, SMEs face severe disadvantages while trying to obtain financing relative to larger and more established firms. On the other hand, leasing is an asset-backed, term financing product. It focuses basically on the ability of lessee's cash flow generation from their regular business operations to service the lease payment, rather than on the asset base. In this connection, this paper investigates how as an alternative financing mechanism, leasing can be the useful tool in facilitating greater access to finance for SMEs. From the survey of the paper it is found that out of $46.67 \%$ who got the access into the formal financial institutions only 7.14 per cent of the enterprises avail the lease facilities. So it is strongly suggested that developing the leasing sector as a means of delivering finance increases the range of financial products in the marketplace and provides a route for accessing finance to SMEs that would otherwise be impossible.
\end{abstract}

Keywords: SME development, Access to finance, Lease financing

\section{INTRODUCTION}

In the developing world Small and Medium Enterprises (SMEs) are playing a vital role in economic development. They are the major and influential players in the economic growth of different developing countries. Bangladesh economy is characterized by lower per capita income, high level of unemployment, mass poverty and social deprivation. In these circumstances, higher growth of SMEs can reduce poverty to a tolerable level by creating jobs for the skilled and unskilled manpower in this sector. Bangladesh is maintaining a steady economic growth of around 6\%, which has become possible because of growth in both agriculture and activities related to micro, small and medium enterprises. The main characteristics of small business are: (i) they are operated by a family or close group; (ii) business owner is the day-to-day decision maker; (iii) formal business records are not 
widely available and even if some formal records are available, information may not be accurate and are rarely audited. Small enterprises are labor intensive businesses and in most of the cases they are able to serve niche market segments that are not covered by the larger businesses. It makes innovative use of knowledge, experience, resources and simple technologies to turn local market conditions into business opportunities.

Most of the small businesses are family-based and lack appropriate financing for their start- up and maintaining the operations. Their access to formal credit is not easier compared to the medium and large enterprises. Levy (1991) highlighted some of the common problems faced by most developing countries, viz., the financing constraints; regulatory constraints; technical, marketing and other non-financial input constraints; and cost constraints. Empirically, it has been tested and found (Beck, Demirgüç-Kunt, and Maksimovic 2005) that lack of access to external finance is a key obstacle to firm growth, especially for SMEs. In most developing countries, capital markets are relatively undeveloped and banks are often unable or unwilling to undertake term lending. Financial institutions prefer to lend to larger, established businesses with well-developed balance sheets and credit histories. A number of studies (Schiffer and Weder, 2001; Beck, Demirguç-Kunt, and Maksimovic, 2005; and Beck, Demirgüç-Kunt, 2006) using firm-level survey data have shown that SMEs not only perceive access to finance and the cost of credit to be greater obstacles than large firms, but see these factors as constraining SMEs (i.e., affect their performance) more than large firms. Most of the entrepreneurs in our country are illiterate and are unable to prepare proper business plan and quality financial statements, lack in quality information, are not able to manage adequate guarantees which often do not enable them to have access into the formal financial sector.

In the above circumstances, a well-functioning leasing industry is an important financing tool to boost up the SMEs in the country. Such enterprises are particularly constrained by the lack of assets that can be used as collateral for bank loans. Many of our SMEs arrange funds from informal sources which is too costly for investment financing. Advantages of leasing over alternative forms of finance for SMEs include a lower down payment, credit availability, simpler documentation and security arrangements, faster credit approval, and tax incentives etc. In promoting the small enterprise in developing countries, leasing plays a role in reducing poverty by generating income and employment. Moreover, a robust leasing industry has the potential to contribute to the development of capital markets by introducing SMEs to formal financial markets and providing demand from leasing companies for capital market funding. SMEs need improved access to finance for their growth especially for acquiring capital equipment and applications of new technology for operations. However, their access to finance is restricted because SMEs generally do not have reliable and audited credit histories, adequate capitalization or additional assets for collateral. Thus, this is the opportunity for the lessor to capture the potential market for selling its products and services. Moreover, leasing can be a source for short- to mediumterm financing for equipment needed by SMEs to expand operations.

\section{Objective OF the Study}

This paper examines the financing constrains of SME sector and to identify how leasing can be the better alternative mechanism for enhancing the growth of the sector. The specific objectives of the paper are:

(i) To identify the present status of SME financing and their financing constrains. 
(ii) To represent the current scenario of lease financing by banks and non-bank financial institutions. and

(iii) To examine how leasing can be used as an alternative financing mechanism for developing SMEs in Bangladesh.

\section{DatA \& METHODOLOGY}

To comply with the objectives of the study, data have been collected both from primary and secondary sources. Primary data includes, both interview and questionnaire survey on the SME sector to identify the present status of SME financing, contribution of leasing toward the sectors and lease financing availed by them from the financial institutions. Sixty (60) enterprises were interviewed through the questionnaire survey that was selected from five districts ${ }^{1}$ based on purposive sampling. While selecting clients for interview and using purposive sampling, several points were kept in mind which are:

i) Clients were selected from the list of financial institutions those are taking loan from them;

ii) More emphasis was given to the clients of urban and semi-urban areas of the five districts where SMEs are concentrated;

iii) Among 60 enterprises, 39 (65\%) from manufacturing, $12(20 \%)$ from trading and 9 (15\%) from the service sector were selected;

iv) More emphasis was given to the manufacturing sector as they are involving with equipments and machineries for their production where leasing can play a vital role;

v) Most of the clients those who are maintaining relationship for more than six months with their existing banks were selected.

However, the study does not cover the SMEs operating in rural areas. Published literature, different books and research papers were reviewed to complete theoretical background and relevant websites were visited to collect secondary information.

The paper is divided into six sections. After a brief background as part of introduction (section 1), section 2 highlights the overview of SME sector. Section 3 reveals an overview of lease financing. Section 4 represents the SMEs access to finance and the survey results. Section 5 identified how leasing can help to achieve financial institutions' and SMEs' objectives? Finally, section 6 represents suggestions and policy implications.

\section{An OVERVIEW OF SME Sector}

The SMEs worldwide are recognized as engines of economic growth. They constitute the dominant form of business organization, accounting for over $95 \%$ and up to $99 \%$ of enterprises depending on the country (OECD, 2006). In Bangladesh small and medium enterprises, including the tiny and 'micro' enterprises comprise about $99.85 \%$ business enterprises outside agriculture, where SMEs comprises 90\% (Rubayat, 2009; Shamsul at el, 2006). During 1992 to 2007, the relative shares of the SMEs in both term loans and working capital loans extended by the banks to the economic sectors hovered around only 2 to 5 percent and 4 to 12 percent respectively (Ahmed, 2010). Despite having huge potential, contribution of SME sector to the country's GDP is still lower than those of many other countries. Presently, the country's SME sector contributes about 25 per cent to the country's total GDP (Financial Express, December 3, 2011). The robustness of SME contributions in employment generation is a common phenomenon in most developing countries. However, the magnitude varies between $70 \%$ and $95 \%$ in Africa and $40 \%$ and $70 \%$ in the countries of the Asia-Pacific region (Ahmed, M.U. 1999).

${ }^{1}$ Dhaka, Narayangonj, Narsingdi, Gazipur and Comilla. 
Performance of the small sector, therefore, has a direct multiplier impact upon the growth of the national economy. Thus, access to finance for small business both for rural and urban areas should be ensured.

\section{SME Definition}

Throughout the world there are a lot of definitions on SME and the researchers and policy makers are far away from a unanimous definition. The definitions that can be found in the literature are heterogeneous in nature. Some of the countries have defined ${ }^{2}$ SMEs in terms of their sales volume, some are on the basis of asset size and some are on the basis of size of capital. In a few countries, a hybrid definition is used such as employment as well as assets. In Bangladesh two definitions existed regarding SMEs; one is in 'SME Credit Policies \& Programmes 2010' published by Bangladesh Bank and other is in the 'Industrial Policy 2010 $3^{\prime \prime}$ published by the Ministry of Industry. Recently Bangladesh Bank has provided a circular (SMESPD, Circular No-1, June, 2011) to determine the size of the SMEs in order to harmonize the definition with the industrial policy. As a result, we have the unique definition for this sector which is shown in Table 1.

Table 1: SME Definition Criteria

\begin{tabular}{|c|c|c|c|}
\hline $\begin{array}{c}\text { Category of } \\
\text { Enterprise }\end{array}$ & Sector & $\begin{array}{c}\text { Fixed Asset other than } \\
\text { Land and Building (Tk.) }\end{array}$ & $\begin{array}{c}\text { Employed Manpower } \\
\text { (not above) }\end{array}$ \\
\hline $\begin{array}{c}\text { Small } \\
\text { Enterprise }\end{array}$ & Service & 5.00 lac -1.00 crore & $10-25$ \\
\cline { 2 - 4 } & Business & 5.00 lac -1.00 crore & $10-25$ \\
\cline { 2 - 4 } & Manufacturing & 50.00 lac -10.00 crore & $25-99$ \\
\hline \multirow{2}{*}{$\begin{array}{c}\text { Medium } \\
\text { Enterprise }\end{array}$} & Service & 1.00 crore- 15.00 crore & $50-100$ \\
\cline { 2 - 4 } & Business & 1.00 crore- 15.00 crore & $50-100$ \\
\cline { 2 - 4 } & Manufacturing & 10.00 crore -30.00 crore & $100-250$ \\
\hline
\end{tabular}

Source: Bangladesh Bank, SME Credit Policies \& Programmes, 2010

According to Table 1, Small and Medium Enterprise means an entity, ideally not a public limited company, which complies with the following criteria:

a) Small Enterprise- A manufacturing concern with total assets at cost including installation of fixed asset and excluding land and building from Tk. 50 lac to 10 crore and/or number of employee ranges from 25 to 99 . A service concern with total assets at cost including installation of fixed asset and excluding land and building from Tk. 5 lac to Tk 1 crore and/or number of employees ranges from 10 to 25. A trading concern with total assets at cost including installation of fixed asset and excluding land and building from Tk. 5 lac to Tk 1 crore and/or number of employees ranges from 10 to 25 .

b) Medium Enterprise- A manufacturing concern with total assets at cost including installation of fixed asset and excluding land and building from Tk. 10 crore to 30 crore and/or number of employee ranges from 100 to 250. A service concern with total assets at cost including installation of fixed asset and excluding land and building from Tk. 1 crore to 15 crore and/or number of employees ranges from 50 to 100. A trading concern with

\footnotetext{
${ }^{2}$ For example, European Commission (January 1, 2005) accepted a new definition based on sales volume, number of employees and asset size.

${ }^{3}$ Industrial policy does not cover the definition for trading concerns.
} 
total assets at cost including installation of fixed asset and excluding land and building from Tk. 1 crore to 15 crore and/or number of employees ranges from 50 to 100.

It is important to note that, if on one criterion, a firm falls into the 'small' category, while it falls into 'medium' category based on the other criterion, the firm will be deemed as in the 'medium' category. On the other hand, if on one criterion, a firm falls into the 'medium' category, while it falls into 'large' category based on the other criterion, the firm will be deemed as in the 'large' category.

\section{Current Status of SME Financing in Bangladesh}

Banks and NBFIs are very important stakeholders in the field of small enterprise financing. They are playing an important role in ensuring access to finance for the small enterprises. The data of the SME \& Special Programmes Department of Bangladesh Bank indicated that the average of all banks and NBFIs total outstanding loan in the SME sector was $22.84 \%$ in 2012 (up to September) whereas the same was $20.12 \%$ in 2011 . Financial Institutions are coming forward with their financing package in small business sector. But it is important to note that, small enterprises access to credit compared to medium enterprises is lower. In 2011 all banks and NBFIs disbursed $48.13 \%$ to small business and $51.87 \%$ to the medium enterprises of their total SME loan.

Table- 1 shows the disbursement of SME loan on the basis of the total SME loans disbursed by the banks and NBFIs in Bangladesh. In 2010, the aggregate disbursement in small enterprises by all banks and NBFIs was $43.02 \%$, while the aggregate disbursement in medium enterprises by all banks and NBFIs was $56.98 \%$. Therefore, the banks' and NBFIs' total SME loan disbursement was concentrated more in medium enterprise sector $(56.98 \%)$ and less in small enterprises sector $(43.02 \%)$.

Table- 1: Disbursement of SME Loan by Banks and NBFIs (Tk. In Crore)

\begin{tabular}{|c|c|c|c|c|c|c|}
\hline Year & \multicolumn{2}{|c|}{2010} & \multicolumn{2}{c|}{2011} & \multicolumn{2}{c|}{2012} \\
\hline $\begin{array}{c}\text { Banks/ } \\
\text { NBFIs }\end{array}$ & $\begin{array}{r}\text { \% of Total } \\
\text { Disbursement }\end{array}$ & \multicolumn{2}{c|}{$\begin{array}{c}\text { \% of Total } \\
\text { Disbursement }\end{array}$} & \multicolumn{2}{c|}{$\begin{array}{c}\text { \% of Total } \\
\text { Disbursement }\end{array}$} \\
\hline & Small & Medium & Small & Medium & Small & Medium \\
\hline SOB & 45.96 & 54.04 & 57.10 & 42.90 & 46.87 & 53.13 \\
\hline SB & 34.25 & 65.75 & 46.44 & 53.56 & 29.12 & 70.88 \\
\hline FB & 47.39 & 52.61 & 47.17 & 52.83 & 50.44 & 49.56 \\
\hline PCB & 42.68 & 57.32 & 46.96 & 53.04 & 54.28 & 45.72 \\
\hline Total Banks & 42.82 & 57.18 & 47.75 & 52.25 & 51.10 & 48.90 \\
\hline NBFIs & 49.17 & 50.83 & 60.22 & 39.78 & 53.89 & 46.11 \\
\hline $\begin{array}{c}\text { Total Banks } \\
\text { \& NBFIs }\end{array}$ & 43.02 & 56.98 & 48.13 & 51.87 & 51.18 & 48.82 \\
\hline
\end{tabular}

Source: SME \& Special Programmes Department, Bangladesh Bank.

SOB- State own banks, SB- Specialized banks, FB- Foreign banks, PCB- Private commercial banks. In 2011, the concentration of total SME disbursement in small enterprises $(48.13 \%)$ and medium enterprises $(51.87 \%)$ remained almost similar to those in the previous year. But in 2012, it is finds that small enterprises (51.18\%) enjoy slightly the higher financing facilities than medium enterprises $(48.82 \%)$. It is important to note that foreign commercial banks increase their market share in financing small enterprises. 
In compare to the banks, NBFIs are disabusing more to the small enterprises than the medium enterprises in the year 2011 and 2012. According to Table 1, it is observes that out of the total disbursement in SMEs NBFIs provide 60.22 percent in small enterprises while commercial banks provide 47.75 percent of their total SME loan disbursement. Similarly in 2012, NBFIs contribute more in the small enterprises sector. Thus, banks should come forward to increase their market share to the small enterprises sector which can help to reduce poverty level and can increase the employment generation to comply the government millennium develop goals.

Table- 2 highlights on the sector-wise disbursement of SME loan by the banks and NBFIs in Bangladesh. The disbursement of SME loan was categorized as service sector, trading sector and manufacturing sector.

Table- 2: Sector-wise Disbursement of SME Loan

\begin{tabular}{|c|c|c|c|c|c|c|c|c|c|}
\hline Year & \multicolumn{3}{|c|}{2010} & \multicolumn{3}{c|}{2011} & \multicolumn{3}{c|}{2012} \\
\hline $\begin{array}{c}\text { Banks/ } \\
\text { NBFIs }\end{array}$ & $\begin{array}{c}\text { \% to } \\
\text { Service } \\
\text { Sector }\end{array}$ & $\begin{array}{c}\text { \% to } \\
\text { Trading } \\
\text { Sector }\end{array}$ & $\begin{array}{c}\% \text { to } \\
\text { Mfg. } \\
\text { Sector }\end{array}$ & $\begin{array}{c}\text { \% to } \\
\text { Service } \\
\text { Sector }\end{array}$ & $\begin{array}{c}\% \text { to } \\
\text { Trading } \\
\text { Sector }\end{array}$ & $\begin{array}{c}\% \text { to } \\
\text { Mfg. } \\
\text { Sector }\end{array}$ & $\begin{array}{c}\% \text { to } \\
\text { Service } \\
\text { Sector }\end{array}$ & $\begin{array}{c}\% \text { to } \\
\text { Trading } \\
\text { Sector }\end{array}$ & $\begin{array}{c}\% \text { to } \\
\text { Mfg. } \\
\text { Sector }\end{array}$ \\
\hline SOB & 3.05 & 61.50 & 35.45 & 3.94 & 60.67 & 35.39 & 1.79 & 60.86 & 37.35 \\
\hline SB & 1.65 & 49.86 & 48.49 & 2.41 & 52.21 & 45.37 & 4.29 & 57.71 & 38.00 \\
\hline FB & 12.81 & 47.93 & 39.27 & 15.00 & 48.59 & 36.41 & 9.44 & 49.71 & 40.85 \\
\hline PCB & 5.11 & 69.59 & 25.30 & 6.56 & 68.82 & 24.61 & 4.96 & 64.81 & 30.23 \\
\hline Total Banks & 4.94 & 67.35 & 27.72 & 6.35 & 66.87 & 26.78 & 4.84 & 63.85 & 31.31 \\
\hline NBFIs & 24.07 & 47.92 & 28.01 & 25.67 & 43.70 & 30.63 & 21.79 & 42.68 & 35.53 \\
\hline $\begin{array}{c}\text { Total Banks } \\
\text { \& NBFIs }\end{array}$ & 5.59 & 66.69 & 27.73 & 6.94 & 66.16 & 26.90 & 5.20 & 63.40 & 31.40 \\
\hline
\end{tabular}

Source: SME \& Special Programmes Department, Bangladesh Bank.

In 2010, the aggregate average of SME loan disbursement by the banks and NBFIs was 66.69\% in trading sector, $27.73 \%$ in manufacturing sector and $5.59 \%$ in service sector. On the other hand, the 2011 figures revealed that $66.16 \%, 26.90 \%$ and $6.94 \%$ were disbursed in trading, manufacturing and services sectors respectively by the banks and NBFIs. Similarly in 2012, it is evident that the trading sector enjoyed more concentration $(63.40 \%)$.

In comparison with banks and NBFIs, Table 2 that banking sector disbursed SME loan largely in the trading sector and least in the service sector, while NBFIs maintained more or less balanced approach in disbursing their SME loan. The aggregate average of SME loan disbursement by the banks and NBFIs was $66.69 \%$ in trading sector, $27.73 \%$ manufacturing sector and $5.59 \%$ in service sector. It is evident that, trading sector is getting more finance from the banks and NBFIs. In case of the disbursement in manufacturing sector, NBFIs provide slightly the higher percentage than banks in both 2011 and 2012. It is important to note that, if the banks and NBFIs do not reallocate their funds for the manufacturing sector then the productive sector would not develop. Bangladesh is at present largely engaged in the manufacture of common consumer goods, requiring rather simple technologies that are predominantly labor-intensive and that do not require a very high degree of skills to produce. Thus, financial access can ensure the better growth for future. In this connection, leasing can be a better solution for developing this sector.

\section{Constraints to SME Growth}


Beck, Demirgüç-Kunt, and Maksimovic (2002) clarify how financial constraints affect firms of different sizes. Their study of 4,000 firms in 54 countries offers evidence that financial constraints affect the smallest firms most adversely and that an incremental improvement of the financial system that helps relax these constraints will be most beneficial for SMEs. Most of the small businesses are family oriented and lack appropriate financing for their start- up and maintaining the operations. Their access to formal credit is not easier compared to the medium and large enterprises. Some studies (EBRD 2004; Hossain 1998; PECC 2003) concluded that the inability of access to credit is one of the major bottlenecks of SME, as almost all of these economies have poorly developed banking sectors. Thus, this financing problem hinders their normal business operations that result in the lack of potentiality for future growth.

High interest rate and excessive collateral requirement inhibit SMEs access to finance from the formal financial institutions. Haque and Mahmud (2003) reveals that, high interest rate, collateral requirement and lack of skills and attitude of bankers are among the most significant problems for small and medium entrepreneurs in availing of finance from the formal financial institutions. Availability of required working capital at appropriate time is another significant problem for most of the small businesses. In his study, Hossain (1998) revealed that SMEs encounter great difficulties while rising fixed and working capital because of the reluctance of banks to provide loans to SMEs. Finally, it can be said that lack of institutional credit, non-availability of working capital, low levels of technology, low productivity, and lack of marketing facilities and market access problems are the major bottlenecks to SME growth in Bangladesh. On the other hand, domestic law and order conditions, unreliable power supply and stiff competition both in domestic and international markets seem to constitute added dimensions to the SME operational bottlenecks.

A recent study (Mamun et. al, 2012) explored main obstacles cited by the entrepreneurs for accessing formal financial sector which are started from high interest rate, excessive security and guarantee requirement, insufficient working capital loan, complexity of documentation, long loan processing time, unstructured financial information, financial institutions' negligence, high sunk cost for obtaining loan, malpractices in sanctioning loan, and lack of managerial capacity.

\section{AN OVERVIEW OF LEASE FINANCING}

Leasing, in general, is viewed as a method of financing for acquisition of capital equipment. Leasing is a medium- term funding facility in the form of an agreement by contract between a lessor and a lessee upon which the latter is entitled to use the lessor's asset in return for regular payment to him/ her for a fixed period of time. At the end of the leasing period, the lessee has the right to buy the equipment. The lessee is usually allowed to deduct the cost of lease rentals from taxable income (Amiri, 1998).

Through leasing, machinery, equipment, vehicles, and/or properties of many businesses can be procured. Rather than investing direct capital, with the help of lease financing any business can fulfill their assets needs like equipment, vehicles, fixture, etc. Lessors purchase the equipment which generally selected by the lessee, and provide it to them for a set period of time. For the duration of the lease, the lessee makes periodic payments to the lessor at an agreed rate of interest. At the end of the lease period, the equipment is either transferred to the ownership of the business, returned to the lessor, discarded, or sold to a third party. Under financial leasing, the lessee typically acquires or retains the asset. 


\section{Current Status of Lease Financing in Bangladesh}

\section{a) Status of Banking Sector}

The leasing business is not new in Bangladesh. Lease financing by banks in Bangladesh is getting force, since section 7 of the Bank Companies Act 1991 has recognized leasing as a legal business for banking company. However, as a provider of leased asset to the lessee, commercial banks started their journey effectively in 1995. Prime Bank Ltd, a private commercial bank in our country, is the pioneer of this sector. It launched lease financing in the year 1995 and sanctioned Tk. 15.26 crores as lease finance during that year. Dhaka Bank Ltd. introduced lease finance in 1997, NCCBL in 1998, Uttara Bank Ltd. and Mercantile Bank in 1999, and EXIM Bank in 2001. Many other banks were subsequently involved in this sector.

Table 3 reveals that from year 2006 to 2011(up to June) lease financing of all banks in Bangladesh gradually increased. But the important point is that the percentage of total investment is not satisfactory. In 2010 banking sector of Bangladesh disbursed only 1.06 per cent of their total investment and 2011(up to June) figure shows only 1.03 per cent. Although the growth (fig.-1) of lease financing shows increasing trend, most of the banks are reluctant for lease financing and their individual figure shows the negative trend.

Table 3: Lease financing of all Banks and their Percentage of total investments.

\begin{tabular}{|c|c|c|}
\hline Year & $\begin{array}{l}\text { Amount } \\
\text { (Tk. in Lacs) }\end{array}$ & $\begin{array}{c}\text { \% of total } \\
\text { investment }\end{array}$ \\
\hline 2006 & 149582 & 1.07 \\
\hline 2007 & 154318 & 0.96 \\
\hline 2008 & 163134 & 0.96 \\
\hline 2009 & 240523 & 1.03 \\
\hline 2010 & 313846 & 1.06 \\
\hline 2011 (June) & 329654 & 1.03 \\
\hline
\end{tabular}

Figure 1: Growth of lease financing in banking Sector of Bangladesh (TK. in Lacs)

Source: Scheduled Banks Statistics, Bangladesh Bank

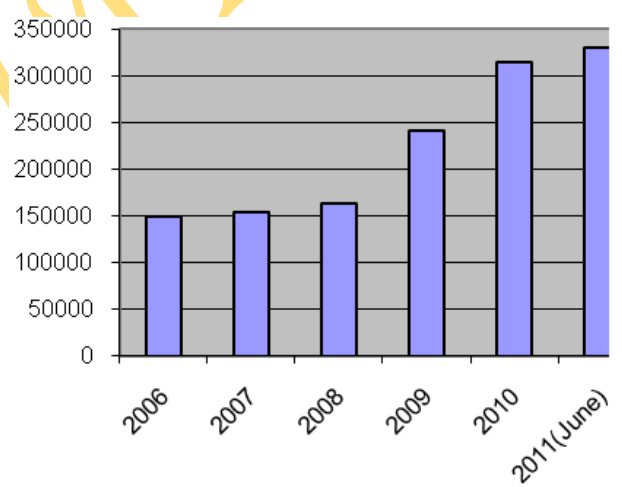

\section{b) Status of Non-banking Sector}

Modern concept of leasing got familiarity in Bangladesh in the year 1986 by setting up of the first leasing company named Industrial Development Leasing Company of Bangladesh Ltd. (IDLC). This was followed by the establishment of United Leasing Company Ltd. (ULC) and UAE-Bangladesh Investment Company Ltd. (UAEBICL) in 1989 etc. Subsequently, First Lease International Ltd. (FLIL) came into the market as a leasing company in 1993. In 1995, two new leasing companies, namely, Uttara Finance and Investment Ltd. (UFIL) and Phoenix Leasing Company Ltd. (PLC) were formed. A boom has been observed in this area in 1996, when five new companies entered in to the leasing industry. About 25 leasing companies are now operating in the country. 
Figure 2: Growth of Lease Finance of all Leasing Companies in Bangladesh (in million Taka)

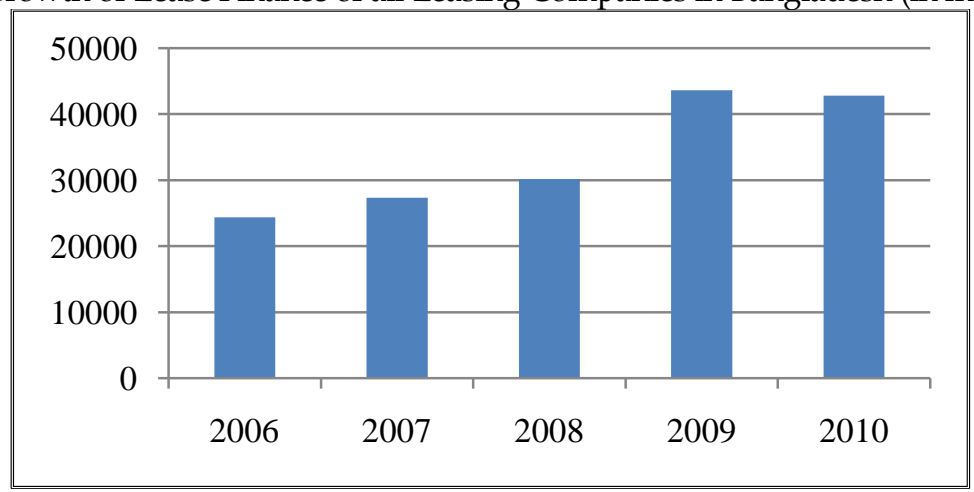

Source: Year Book 2008 of Bangladesh Leasing \& Finance Companies Association \& Annual Report of NBFIs 2010.

The total amount of lease financing by the individual leasing companies in Bangladesh are represented in appendix 1. Fig-2 highlights the growth of lease finance of all leasing companies in Bangladesh. From the figure it is clear that the growth of total lease financing in our country shows a positive trend from the year 2006 to 2009. But it is remarkable that in 2010, total investment in the lease assets has decreased. It is indicating that except a few, most of the leasing companies have somewhat moved away from their core activities.

The percentage of lease finance to total Loans, Advances \& Lease are shown in Fig- 3. From appendix-1, it is observed that, except three companies, all the leasing companies show a lower percentage of lease finance to total loan, advances \& leases in 2010 in comparison to 2009. This indicates that most of the leasing companies are moving towards other forms of financing rather than their traditional activity of lease financing. In 2009, all leasing companies invested 36\% of total loans, advances \& leases to the lease assets whereas in 2010 the same rate stood at $29 \%$ (fig-3). Thus, if the total lease finance is disregarded to different sectors, definitely the investment of lease asset into the SMEs sectors will also decline.

Figure 3: Percentage of Lease Finance to Total Loans, Advances \& Leases by all Leasing Companies in Bangladesh

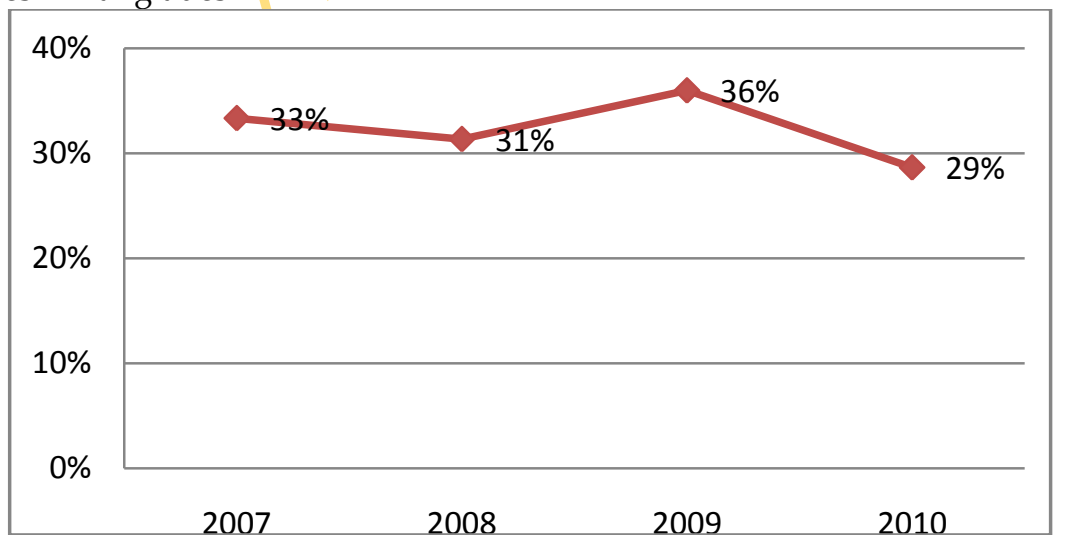

Source: Year Book 2008 of Bangladesh Leasing E Finance Companies Association E Annual Report of NBFIs 2010. 
Note: It is important to note that the size of the total lease finance in the SME sector is not available both for the banking and non-banking sectors. However, from the survey of 60 SME clients it was found that their total financing through leasing was about 7.14 per cent.

In comparison to the banks, NBFIs are concentrating more in lease financing. In 2010 they invested as much as 29 per cent of their total portfolio. But the investment in lease assets by the commercial banks was only 1.06 percent of their total portfolio. It is happening because; the aim of NBFIs is to focus on leasing and the other form of structured finance. Although their concentration is more than the banking sector, the overall percentage of their total lease finance is not remarkable with the negative growth in 2010 from the previous year. Thus, both banks and NBFIs especially the later group should come forward, with maintaining the positive growth in lease financing, in order to boosting the manufacturing sectors as well as the total economy of the country.

\section{SMEs Access to FinANCE: SURVEy RESULT}

The survey of the study finds that only 46.67 per cent of the enterprises got the access into the formal financial institutions while the other 53.33 did not get the access at all (Fig-4). Those who did not get access from the formal credit are operating their business by using different sources of finance like, own source, parents, friends and relatives, informal money lenders ${ }^{4}$, NGO/MFI group etc. Out of 53.33 per cent who did not get loan, 21.87 per cent of the enterprises tried several times to get the access but failed to obtain the loan from the formal sources of credit.

Figure 4: Business Enterprises Access to Formal Credit

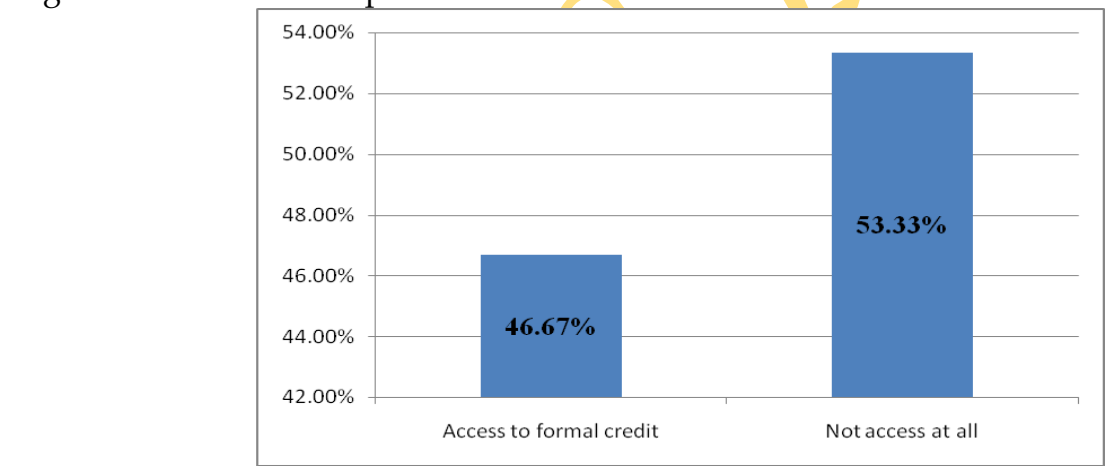

Source: Author's calculation based on survey questionnaire

Choudhury \& Raihan (2000) conducted a survey on SME access to credit under SAPRI study where they found that, "the access to formal credit is not available at all to 50.53 percent of the stakeholders. Only 35.79 percent of SME stakeholders enjoy unrestricted access to the formal credit. The rest (13.68 percent) of them have restricted access to the formal credit". From their very recent survey Mamun, Mosharref \& Mizan (2012) found that $60.31 \%$ of the small enterprises got the access into the formal credit while the other 10 . $41 \%$ enterprises did not have their access at all. On the other hand, 29.27\% of enterprises did not apply for formal credit as they managed their funds by themselves. Thus it can be said that, both in the developing and developed world small firms have been found to

${ }^{4}$ Large part from Multipurpose Cooperatives

Asian Business Consortium, USA $\mid A B C-J A R$ 
have less access to external finance and to be more constrained in their operation and growth (Berger and Udell, 1998; Galindo and Schiantarelli, 2003).

From the questionnaire survey it was found that out of $46.67 \%$ who got the access into the formal financial institutions only 7.14 per cent of the enterprises avail the lease facilities (fig- 5).

Figure 5: Different types of financing facilities availed by SMEs from formal financial institutions (Mixed Responses)

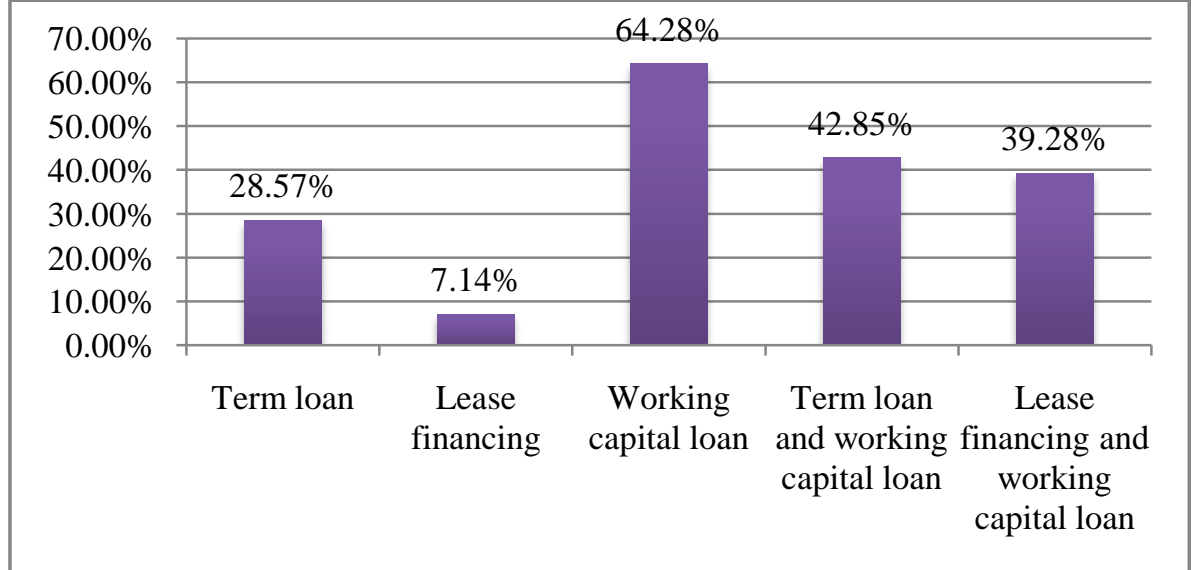

Source: Author's calculation based on survey questionnaire

Again most of the enterprises claimed that the normal rate charged by the financial institutions for the lease financing is much higher than the rate charged for term loan and for working capital loan. Thus, considering the growth of lease finance companies, the share of lease finance in SME sector of total disbursement is very insignificant in the sample study. Figure- 5 also demonstrate that most of the businesses $(64.28 \%)$ enjoy working capital facilities while only 28.57 per cent business got the term loan facilities although there is a very urgent need for the development of SMEs especially for start-up business.

\section{How leasing can Help to Achieve financial Institutions' and SMEs' OBJECTIVES?}

One of the most popular asset financing products in most of the industrialized world is leasing. It is very common in many developing countries but has yet to become popular in our country. This most occurred, as SMEs encountered many problems and banks are dependent on collateral and personal relationships with customers for securing repayments and also in case of payment defaults, to get back of a leased asset is difficult. For a developing country like Bangladesh, leasing can easily help both the financial institutions and their SME clients to reach their objectives. Table 4 represents the financial institutions and SMEs objectives, and how leasing can help achieving such objectives. 
Table 4: Financial Institutions and SMEs Objectives, and How Leasing Can Help Achieve Such Objectives

\begin{tabular}{|c|c|c|}
\hline $\begin{array}{l}\text { Stake- } \\
\text { holder }\end{array}$ & $\begin{array}{c}\text { Possible } \\
\text { Objectives }\end{array}$ & How Leasing Can Help Achieve Stakeholder Objectives \\
\hline \multirow[t]{3}{*}{$\begin{array}{l}\text { Lessees/ } \\
\text { SMEs }\end{array}$} & $\begin{array}{l}\text { - Access to } \\
\text { finance }\end{array}$ & $\begin{array}{l}\text { - No/low collateral required. } \\
\text { - The cost of lease finance is competitive with traditional } \\
\text { credit, given the increased security held by lessors and } \\
\text { the low transaction costs of processing a lease. } \\
\text { - Leasing also offers matched maturity of } \\
\text { assets/liabilities, since debt in emerging countries is } \\
\text { often limited to short-term maturities. } \\
\text { - Islamic compliance: in Muslim countries, leasing is seen } \\
\text { as an interest- free product and considered the same as } \\
\text { a rental. }\end{array}$ \\
\hline & $\begin{array}{l}\text { - Access to } \\
\text { equipment and } \\
\text { production } \\
\text { assets }\end{array}$ & $\begin{array}{l}\text { - Leasing increases flexibility and diversification of } \\
\text { financing sources. } \\
\text { - Leasing enables investment in equipment that can } \\
\text { modernize production and improve productivity and } \\
\text { profitability. } \\
\text { - Leasing reduces maintenance cost, since equipment is } \\
\text { newer. } \\
\text { - Due to reduced upfront costs, leasing frees up capital } \\
\text { for other business needs. }\end{array}$ \\
\hline & $\begin{array}{l}\text { - Ability to plan } \\
\text { - Timeliness and } \\
\text { flexibility } \\
\text { - Negotiability }\end{array}$ & $\begin{array}{l}\text { - Leasing enables companies to match income and } \\
\text { expenditure. } \\
\text { - Leasing also has advantages of a quick decision-making } \\
\text { process, flexibility, and negotiability. } \\
\text { - Leasing deals may make less use of the restrictive covenants } \\
\text { that appear in more traditional forms of lending. } \\
\text { - Where lessors have asset knowledge or relations with } \\
\text { suppliers, lessees may "outsource" certain tasks (such } \\
\text { as negotiating with suppliers), reducing costs and risks. } \\
\text { - Independence from bank borrowing: through leasing, SMEs } \\
\text { have alternative funding opportunities and are able to use a } \\
\text { mix of funding options to finance their businesses. }\end{array}$ \\
\hline \multirow[t]{2}{*}{$\begin{array}{l}\text { Lessors } \\
\text { (includin } \\
\text { g banks) }\end{array}$} & $\begin{array}{l}\text { - Risk } \\
\text { management } \\
\text { / reduction }\end{array}$ & $\begin{array}{l}\text { - The lessor maintains legal ownership of the asset. } \\
\text { - The lessor is able to exert greater control over the } \\
\text { investment. } \\
\text { - The lessor can monitor assets more easily. } \\
\text { - Lessors can actively apply specialized knowledge, such } \\
\text { as equipment specialization. }\end{array}$ \\
\hline & $\begin{array}{l}\text { - Leasing market } \\
\text { development } \\
\text { - Product } \\
\text { portfolio } \\
\text { diversification } \\
\text { - Customer base } \\
\text { expansion }\end{array}$ & $\begin{array}{l}\text { - Leasing provides not just an opportunity to extend product } \\
\text { lines, but also to deepen the organizational structure. } \\
\text { - In some cases, leasing may allow businesses accessing } \\
\text { both lease financing and additional bank financing } \\
\text { without increasing their collateralized debt. } \\
\text { - Leasing can provide additional marketing channels for } \\
\text { financial services. }\end{array}$ \\
\hline
\end{tabular}

Source: IFC (2005) 


\section{SUGgestions AND POLICY IMPLICATIONS}

From the survey and other literature, it is observed that leasing business in Bangladesh moved away from regular leasing activities to some other form of financing. The broader sectors of the economy that now receive lease financing services are textiles, apparels and accessories, transport, construction and engineering, paper and printing, pharmaceuticals, food and beverage, chemicals, agro-based industries, telecommunications, and leather and leather products etc. There is a huge potentiality of lease products developed by the financial institutions in Bangladesh. Thus, keeping mind on these opportunities, leasing can play different strong roles as an alternative financing mechanism. Following are some suggestions based on the survey and literature for the effective use of leasing products as the alternative financing mechanism in Bangladesh:

- The most familiar sources of finance for SMEs are internally generated cash, banks/nonbank financial institutions loans and capital markets. For start-up business, entrepreneur needs a huge amount of money, especially for the manufacturing business, where no formal institutions have the interest. As a result, entrepreneurs are depending on their own funds or borrow from friends, relatives, informal moneylenders or arrange a partnership. Moneylenders charge high interest rate and some time at the growth stage, friends or relatives demand their portion in some unusual time or there may be some conflicts between/among partners. In this context, leasing or supplier's credits may be the only source of external financing for SMEs' growth.

- In Bangladesh, capital markets are relatively undeveloped and SME have less access to such market for arranging funds. In the early stage or even in the matured stage, they lack credit worthiness as well as public confidence. In these circumstances, leasing can become an important financing technique for this sector. Leasing may be the only recourse to external financing, because ownership of the asset financed does not transfer to the borrower until after the lease obligation has been fully discharged.

- Most of the bank/non-bank financial institutions are reluctant to provide long term loan because of the risks involved and their longer gestation period. As banks and other development financial institutions show poor recovery and fund recycling performances, leasing got the opportunity to develop as an alternative source of funding. The down payments in leasing are not high and the gestation period is low. Traditional banks often prefer to lend to larger, well established businesses that have a sound track record and can offer stronger security and are also unwilling to undertake term lending. Leasing company, in this prospective market, may involve themselves to serve and get the benefits.

- The selection of lease proposals is relatively free from extraneous pressure and is subject to a quality level appraisal. Speed and low loan processing time are much important for SME clients. Leasing companies can attract clients by providing relatively better services with short loan processing time. Because leasing generally does not require additional collateral and follow simplified documentation, and because leasing companies are more focused and specialized, lease financing is made available to SMEs more effectively and with lower internal processing costs than term loans.

- Leasing focuses on the lessee's ability to generate cash flow from business operations to service the lease payment, rather than on the balance sheet or past credit history. As a result, it is particularly advantageous for new, small and medium-size businesses that do not have a lengthy credit history or a significant asset base. Thus, the SMEs 
who have strong and consistent cash flow can attract the leasing company for their business expansion.

- Another important barrier of SME access to finance in the formal financial institutions is the lack of diversified and customized products available at banks and many other leasing companies. Thus, developing the leasing sector as a means of delivering finance increases the range of financial products in the marketplace and provides a route for accessing finance to SMEs that would otherwise be impossible.

- Traditional bank's asset-based financing generally requires a borrower to provide up to $40 \%$ of the cost of the asset to be acquired, since a loan may cover only $60 \%$ of the asset value. In some cases, borrower requires another asset in addition to the one being acquired as security. In contrast, a lease arrangement typically requires the owner/borrower to provide and fund $10 \%$ of the asset cost as up-front security deposit. The asset itself serves as collateral for the transaction since ownership of the asset is retained by the lessor during the term of the lease. Thus, leasing can finance a higher percentage of the capital cost of equipment thereby allowing the business entity to preserve its cash resources or existing bank facilities to meet working capital needs.

- Due to the lack of strong monitoring and supervision more often it is found that some SME clients involve with funds diversion activities. As a result, the objective of financial institutions financing may not be achieved. However, under the leasing arrangement lessor is involved with the buying process of the asset which increases the security and subsequently can overcome the possibility of funds diversion. So, in order to remove such problems bank and other financial institutions may introduce leasing products in their products' portfolio.

- Through the mechanism of sale and lease back, SME can unlock initial capital that has been needed otherwise to finance their start-up phase of business. By unlocking such money they can easily use it as to fulfill their working capital need rather than depending on the financial institutions. In this context, leasing can be the best alternative for working capital financing.

- Both lessor and the lessee enjoy the tax benefits which increase their profitability. For the lessee, full lease rental is an expense. Lessees can offset their full lease payments against income before tax, compared to just the depreciation allowance or interest charges on bank loans'. There are also VAT advantages in some cases. On the other hand, lessor can able to claim tax relief on the depreciation of the asset which also increase their profit. So, leasing can be the better alternative financial product for improving the profitability of the SMEs by reducing the amount of taxes.

- Increased investment in the energy sector as well as in power, transport, telecommunications, water and sanitation, and safe disposal of wastes is expected to bring further opportunities for leasing industries. For example, the bank's experience in Pakistan and Indonesia, and those of other multilateral agencies in other country programs particularly in alternative energy systems indicates the significant potential of leasing as a financial product to assist in the growth and expansion of SMEs. Therefore, in Bangladesh financial institutions may help SMEs through their leasing products, existing or potential, which are involving as the backward linkage business of large industries.

Finally in can be concluded that, financing small and medium enterprises is not a matter of option; rather it is the need of time. Realizing the fact, financing to SMEs has grown significantly in recent years and it is becoming a strategic segment for financial institutions 
in Bangladesh. There is a good potential for the leasing market in Bangladesh. However, there are still several constraints, both on the leasing as well as the SME levels. As a financing technique, leasing has been effective in overcoming barriers posed by SME sector. This sector can offer new market opportunities for leasing companies. Lack of collateral and cash flow-oriented operations of SMEs can make them attractive to the leasing companies. On the other hand, because of short loan processing time and low documentation cost leasing companies can easily enter into this segment for gaining competitive advantage over the traditional banks. In turn, leasing can provide new ways to acquiring the use of an asset as an alternative to outright purchase using borrowed funds, which are generally in very limited supply. At the same time, different stakeholders should come forward enthusiastically with their intention to ensure the better future growth of SME sector by providing new products and services including leasing facilities that can contribute more in the economy in terms of GDP growth, employment creation, income generation, export earnings etc. in this regard, the suggestions of the paper may be adopted by the policy makers for their future decision making.

\section{REFERENCES}

Ahmed, Momtaz Uddin, (1999), "Development of Small-scale Industries in Bangladesh in the New Millennium: Challenges and Opportunities", Asian Affairs, Vol. 21, No.1.

Ahmed, Momtaz Uddin, (2010), “Essays on Contemporary Development: Issues of Bangladesh", A H Development Publishing House.

Alam, Md Shamsul et al., (2006), "SMEs in Bangladesh and their Financing: An Analysis and some Recommendations", The Cost and Management, Vol 34, No. 3

Amiri, Mohamed (1998), "Challenges and opportunities in reaching SME through Leasing 'Egypt Experience'”, available at http://archives.entreprendremediterranee.com/documents/colloque-Acim-tunis-2006/Session3/Amiri-Egypteanglais.pdf, last access august 28, 2013.

Beck, T. and Demirgüç-Kunt, A., (2006), "Small and Medium-Size Enterprises: Access to Finance as a Growth Constraint", Journal of Banking and Finance, 30: 2931-2943.

Beck, T., Demirgüç-Kunt, A., and Maksimovic, V., (2005), "Financial and Legal Constraints to Firm Growth: Does Firm Size Matter?" Journal of Finance, 60: 137-177.

Beck, Thorsten, Asli Demirgüç-Kunt, and Vojislav Maksimovich (2002), "Financing Patterns Around the World: The Role of Institutions", Policy Research Working Paper 2905, World Bank, Washington, DC

Berger, A.N., Udell, G.F., (1998), "The economics of small business finance: The roles of private equity and debt markets in the financial growth cycle", Journal of Banking and Finance 22, 613-673.

Choudhury \& Raihan, (2000), "Structural Adjustment Participatory Review Initiative, Bangladesh Study Theme 2(C) : Implications of Financial Sector Reforms", available at http://saprin.org/bangladesh/research/ban_finance.pdf.

EBRD, (2004), "SME Finance in the Early Transition Countries: The EBRD"s Experience", European Bank of Reconstruction and Development, accessed from http://www.ebrd.com/ pubs/legal/lit042h.pdf.

Financial Express, (December 3, 2010), A Daily News Paper of Bangladesh, International Publications Limited, Dhaka, Bangladesh.

Fletcher, Matthe et. al., (2005), "Leasing in Development, Lessons from Emerging Economies”, International Finance Corporation, Washington,D.C.

Galindo, A., Schiantarelli, F. (Eds.), (2003), "Credit constraints and investment in Latin America", Inter-American Development Bank, Washington, DC. 
Gallard, Joselito, (1997), "Leasing to Support Small Businesses and Microenterprises", Policy Research Working Paper no 1857, Financial Sector Development Department, The World Bank.

Haque, A.K. Enamul, and Mahmud, Sakib, (2003), "Economic Policy paper on Access to Finance to SMEs: problems and remedies", The DCCI-CIPE, ERRA Project

Hossain, Najmul, (1998), "Constraints to SME Development in Bangladesh", JOBS project, U.S.A.I.D, USA

IFC, (1996), "Leasing in emerging markets", Lessons of Experience Series, IFC, Washington.

Levy, Brian (1991), "Obstacles to Developing Small and Medium-Sized Enterprises”, Working Paper Series No 0588, The World Bank.

Mamun, Ashraf Al, Hossain, Md. Mosharref and Mizan A.N.K, (2012), “SME Financing: Demand Side Problems and Supply Side Responses", research paper presented at BIBM seminar at April 7, 2012.

Molenaar, K. (2006), "Business Development Services, a key issue too often forgotten", FACET BV

OECD (2006), "Financing SMEs and Entrepreneurs, Policy brief", available at http://www.oecd.org/publications/Policybriefs.

PECC, (2003), "Financing Small and Medium Enterprises Challenges and Options", Issues@PECC, Pacific Economic Cooperation Council.

Rubyat, Jasmin, (2009), “Financing Small Scale Industries in Bangladesh: The much talked about but less Implemented Issue", Proceeding of ASBBS Annual Conference, Vol 16, Las Vegas.

Schiffer, M. and Weder, B., (2001), "Firm Size and the Business Environment: Worldwide Survey Results", International Finance Corporation Discussion Paper 43.

Small and Medium Enterprise (SME) Credit Policies \& Programmes, (2010), SME \& Special Programmes Department, Bangladesh Bank.

Small and medium-sized enterprises (SMEs), what is an SME?, http://ec.europa.eu/enterprise/policies/sme/facts-figures-analysis/smedefinition/index_en.htm. 
Appendix 1: Investment in Lease Asset and its percentage to Total Loan, Advances and Leases by all Leasing Companies in Bangladesh (Tk. in million).

\begin{tabular}{|l|c|c|c|c|c|c|c|c|}
\hline \multicolumn{2}{|c|}{ Name of NBFIs } & \multicolumn{3}{|c|}{ Lease Financing } & \multicolumn{3}{c|}{$\begin{array}{c}\text { \% of lease finance } \\
\text { to total Loans, } \\
\text { Adv Leases }\end{array}$} \\
\hline & $\mathbf{2 0 0 7}$ & $\mathbf{2 0 0 8}$ & $\mathbf{2 0 0 9}$ & $\mathbf{2 0 1 0}$ & $\mathbf{2 0 0 7}$ & $\mathbf{2 0 0 8}$ & $\mathbf{2 0 0 9}$ & $\mathbf{2 0 1 0}$ \\
\hline BdFin & 514.82 & 488.03 & 1038.99 & 1078.15 & 0.49 & 0.33 & 0.48 & 0.36 \\
\hline BIFC & 613.13 & 722.08 & 985.94 & 1089.17 & 0.37 & 0.28 & 0.26 & 0.21 \\
\hline BAY & 980.31 & 824.27 & 1337.72 & 1247.1 & 0.76 & 0.35 & 0.52 & 0.49 \\
\hline FIDELITY & 309.89 & 232.91 & 253.08 & 157.06 & 0.38 & 0.24 & 0.24 & 0.08 \\
\hline FAREAST & 534.11 & 521.73 & 812.18 & 703.33 & 0.37 & 0.29 & 0.41 & 0.18 \\
\hline FIRST LIL & 1025.15 & 716.63 & 1062 & 1156 & 0.83 & 0.61 & 0.80 & 0.67 \\
\hline GSPFCBL & 880.15 & 1017.64 & 1395.72 & 1227.15 & 0.53 & 0.56 & 0.74 & 0.75 \\
\hline IDLC & 2722 & 2778.89 & 4382.95 & 4106.82 & 0.22 & 0.18 & 0.22 & 0.19 \\
\hline Islami FIL & 816.8 & 971.18 & 1566.9 & 1790.03 & 0.40 & 0.40 & 0.56 & 0.56 \\
\hline ILFSL & 2407.94 & 2715.01 & 4328.51 & 3400.41 & 0.32 & 0.37 & 0.41 & 0.26 \\
\hline IIDFCL & 2083.72 & 2891.49 & 3218.22 & 2545.63 & 0.36 & 0.46 & 0.39 & 0.29 \\
\hline IPDC & 1199.02 & 1069.31 & 1642.85 & 1280.09 & 0.26 & 0.22 & 0.36 & 0.31 \\
\hline LANKA & 1080.71 & 983.67 & 1712.21 & 969.27 & 0.26 & 0.17 & 0.21 & 0.10 \\
\hline MIDAS FL & 350.8 & 350.54 & 450.87 & 739.92 & 0.31 & 0.20 & 0.20 & 0.21 \\
\hline NatFin & 60.61 & 135.93 & 347.9 & 359.21 & 0.44 & 0.41 & 0.66 & 0.44 \\
\hline NHFIL & 703.43 & 637.64 & 906.56 & 708.57 & 0.51 & 0.20 & 0.25 & 0.18 \\
\hline PRIME & 1162.3 & 995.87 & 1623.1 & 1339.52 & 0.35 & 0.25 & 0.22 & 0.15 \\
\hline PLFSL & 1555 & 2094.45 & 2698.1 & 4302 & 0.44 & 0.41 & 0.36 & 0.35 \\
\hline PHOENIX & 2124.08 & 2541.92 & 2051.45 & 2580.83 & 0.39 & 0.42 & 0.29 & 0.30 \\
\hline Premier & 788.62 & 1312.73 & 2329.12 & 2217 & 0.30 & 0.41 & 0.63 & 0.59 \\
\hline Reliance & 418.23 & 539.27 & 974.75 & 928.35 & 0.34 & 0.50 & 0.49 & 0.17 \\
\hline UCL & 1983 & 1542 & 1813.28 & 2255.14 & 0.79 & 0.47 & 0.39 & 0.38 \\
\hline ULCL & 926.63 & 1260.47 & 5016 & 5087 & 0.14 & 0.17 & 0.70 & 0.67 \\
\hline UFI & 2125.31 & 2844.64 & 1704 & 1521 & 0.26 & 0.44 & 0.24 & 0.16 \\
\hline Total & 27365.76 & 30188.3 & 43652.4 & 42788.75 & 0.33 & 0.31 & 0.36 & 0.29 \\
\hline
\end{tabular}

Source: Year Book 2008 of Bangladesh Leasing \& Finance Companies Association \& Annual Report of NBFIs 2010. publishing and delivering superior, Peer-reviewed standard research 